be gained of the astronomical numbers of these freeswimming larvæ. They form part of that section of the marine fauna which, although known to be present, inevitably escapes record in samples of the plankton.

Elizabeth Meyerhof.

Aston Wold,

Peterborough.

August 19.

\section{A Possible Case of Polyploidy in a Prosobranch Mollusc}

IN his recent useful summary in NATURE of July 27, on evidence for polyploidy in hermaphrodite groups of animals, Dr. M. J. D. White remarks that in the pulmonate molluses (Helix pomatia possibly excepted) there is no evidence of polyploidy. Dr. White will therefore be interested in a possible case in another group of molluscs. The species concerned is the parthenogenetic Potamopyrgus jenkinsi Smith, of brackish waters. The British form has been studied by my assistant, Dr. Ann R. Sanderson, and in her absence from home (she has been in Australia for some time) her findings were reported for her at the Dundee meeting of the British Association in $1939^{1}$. Her more detailed paper ${ }^{2}$ has been in the press for some time, but war conditions have delayed publication.

Briefly, the British form of $P$. jenkinsi has a diploid chromosome number of between 36 and 44 but Rhein, in a preliminary note ${ }^{3}$ without figures or details, stated previously that a Continental form had a diploid constitution of 20-22. The species is very difficult to study cytologically, but Dr. Sanderson's careful studies allow no other interpretation regarding the chromosome constitution of the British form, so that, unless Rhein has misinterpreted his preparations, the possibility exists that the British form is polyploid, and presumably tetraploid, by comparison with Rhein's Continental form.

Comparisons with British forms of related species and with an Australian form of $P$. jenkinsi are being made by Dr. Sanderson, but all that may be reported at the moment is that the dicecious British form of Peringia ulva (Pennant) shows a diploid count of 36. It may also be mentioned that the only other known parthenogenetic snail, the American Campeloma rufum Haldeman, recently studied by Mattox ${ }^{4}$, has a diploid count of 12 .

University College, University of St. Andrews, Dundee.

1 Sanderson, "British Association, Journal of Sectional Transactions" p. 90 (1939).

${ }^{2}$ Sanderson, Proc. Zool. Soc., A (in the press, 1940).

${ }^{3}$ Rhein, Naturwiss., 6 (1935).

-Mattox, Z. Zellforsch., 27 (1937).

\section{A Species of Mosquito (Diptera, Culicidæ) New to Britain}

On August 20, when examining a batch of larvæ collected that morning at Portsmouth, I found a third instar larva of the culicine mosquito Theobaldia (Allotheobaldia) longiareolata Macquart, a species which has not hitherto been recorded in Great
Britain. A further search next day yielded four more third and two fourth instar larvæ.

Other species collected in association with them were Anopheles claviger, pupa Aedes detritus, Theobaldia annulata, Tsubochrea, and Culex pipiens larvæ and pupæ, of which the Aedes was the dominant species.

The batch of larvæ and pupæ in question were collected from a small pool of rather foul, slightly saline, water at the northern, inner, silted up end of a moat and where a mixed collection of rubbish had been discharged. There was a strong growth of Spartina Townsendi on the southern margin.

Dr. Edwards states that $T$. longiareolata is distributed "throughout the Mediterranean and in most of the Atlantic Islands. . . . In France it has been taken as far north as Rambouillet (Villeneuve) but it appears to be unknown in central and northern Europe".

$$
\begin{gathered}
\text { British Mosquito Control Institute, } \\
\text { Hayling Island, } \\
\text { Hampshire. } \\
\text { August } 26 .
\end{gathered}
$$

John Staley.

\section{Blind Seed Disease of Rye-Grass}

THE -recent communication by Muskett and Calvert ${ }^{1}$ concerning the presence of blind seed disease of rye-grass prompts me to put on record the following observations so far made at Wye, Kent, with material collected in east Kent.

In the winter of 1939 a total of twenty-seven samples of rye-grass seed was submitted to me by a firm of seedsmen with a request that they be examined for a disease thought to be caused by Pullularia species. Most of the samples were from old pastures and some from more recently sown Kent indigenous rye-grass ('once-grown'). Tests made by the firm had shown that germination was low for all samples except two which had been specially grown from strains produced at the Welsh Plant Breeding Station, Aberystwyth.

The individual samples were examined on a diaphanoscope and the least translucent and the opaque seeds were selected for dissection. It was found that no less than twenty-five of the samples provided seeds which bore on the caryopsis conidia agreeing with those described by Neill and $\mathrm{Hyde}^{2}$ as being produced by the blind seed fungus. Cultures made from surface-sterilized caryopses, together with some of the selected seeds, were submitted to Neill at Auckland, New Zealand, who expressed the opinion that the cultures were apparently identical with those obtained in New Zealand from 'blind seeds' of rye-grass and that the seeds themselves were also typical. The presence of the blind seed fungus within the caryopses of rye-grass seed from these samples of low germination strongly suggests that the disease is widespread in the fields of east Kent.

Following the method carried out by Neill and $\mathrm{Hyde}^{2}$, fifty seeds from each of three of the above twenty-five infected samples were sown in separate pots of sterilized soil and placed in an unheated glasshouse. The sowing was carried out on February 21 and regular observations were made. A number of the seeds from each sample germinated and produced plants. By June 11, a time when the first spikes were flowering, one of the 'blind seeds' from 